\title{
Temporal transcription of the lactococcal temperate phage TP901-1 and DNA sequence of the early promoter region
}

\author{
Peter L. Madsen† and Karin Hammer
}

Author for correspondence: Karin Hammer. Tel: +45452524 96. Fax: +4545882660. e-mail: kh@im.dtu.dk

Department of

Microbiology, Building 301,

Technical University of

Denmark, 2800 Lyngby,

Denmark

\begin{abstract}
Transcriptional analysis by Northern blotting identified clusters of early, middle and late transcribed regions of the temperate lactococcal bacteriophage TP901-1 during one-step growth experiments. The latent period was found to be $65 \mathrm{~min}$ and the burst size $40 \pm 10$. The eight early transcripts, all mapping in a $13 \mathrm{~kb}$ region adjacent to the attachment site of TP901-1, were present at maximal levels $\mathbf{1 0}$ min after infection. The four middle transcripts, observed at maximal levels $\mathbf{3 0}$ min after infection, are all located within a 2 kb region at the distal end of the early transcripts. The late class of transcripts were detected $\mathbf{4 0} \mathrm{min}$ after infection and the amounts of these transcripts increased with time. The late transcripts were localized to the $13 \mathrm{~kb}$ region adjacent to the $\mathbf{2 ~ k b}$ middle transcribed region. The sequence of almost $4 \mathbf{k b}$ of the early region was determined, allowing a detailed transcriptional map for the early region of which in total $6.4 \mathrm{~kb}$ was sequenced. Sequence analysis of the early region revealed two closely positioned but divergently orientated promoters, $P_{L}$ and $P_{R}$, in accordance with the orientation of the ORFs and the transcriptional map. Nine ORFs were found, and similarities to a phage repressor, a single-stranded DNA-binding protein, a topoisomerase, a Cro-like protein and two other phage proteins of unknown function were detected. The gene arrangement in the early transcribed region of TP901-1 thus consists of two transcriptional units: one from $P_{R}$ containing four genes, of which at least two (the integrase gene and putative repressor) are needed for lysogeny, and the divergent and longer transcriptional unit from $P_{L}$, presumably encoding functions required for the lytic life cycle. ORFs with homology to proteins involved in DNA replication were identified on the latter transcriptional unit.
\end{abstract}

Keywords: lactococcal bacteriophage, temporal transcription, mRNA analysis, early promoter, one-step growth

\section{INTRODUCTION}

Lactococcus lactis is used extensively in the dairy industry, particularly for the manufacturing of cheese. Since the fermentations are not performed using sterile conditions, phage infections are a major problem (Sanders, 1987). With the aim of constructing phageresistant starter cultures, naturally occurring phage

\footnotetext{
†Present address: Section on Microbial Genetics, Laboratory of Molecular Genetics, National Institute of Child Health and Human Development, National Institutes of Health, Bethesda, MD 20892, USA.

The EMBL accession number for the sequence reported in this paper is Y14232.
}

resistance mechanisms in L. lactis have therefore been studied quite intensively (for a recent review see Daly et al., 1996). A different approach is to increase the knowledge of the molecular biology of the attacking phages and through this to design new phage resistance modules. Molecular knowledge of selected phage functions, such as lysis functions, origin of replication, site-specific integration functions and transcriptional regulators has been obtained from several lactococcal bacteriophages since 1989 (Shearman et al., 1989; Hill et al., 1990; Lillehaug \& Birkeland, 1993; O'Sullivan et al., 1993; Christiansen et al., 1994; van de Guchte et al., 1994a, b; Arendt et al., 1994; Birkeland, 1994; Boyce $e t$ al., 1995a, b; Nauta et al., 1996; O'Sullivan et al., 1996), 
and these gene cassettes are expected to serve as important genetic tools for the future general engineering of industrial lactococcal starter strains, in addition to the phage resistance aspect. More recently, DNA sequence analysis of entire lactococcal phage genomes has been performed and so far the published reports encompass three virulent phages, the prolateheaded related phages $c 2$ and bIL67, and the small isometric-headed phage $\mathrm{sk} 1$, and one temperate phage, $\mathrm{r} 1 \mathrm{t}$, also having a small isometric head (Lubbers et al., 1995; Schouler et al., 1994; Chandry et al., 1997; van Sinderen et al., 1996).

TP901-1 is a temperate lactococcal phage and like r1t it belongs to the P335 class of small isometric phages (Jarvis et al., 1991; Braun et al., 1989). This class of phages is particularly interesting since it contains both virulent and temperate phages. We have initiated a molecular study of TP901-1 and have previously described an integration system based on a new type of an extended resolvase-like integrase found in TP901-1 (Christiansen et al., 1996).

To provide a foundation for later studies of the gene regulatory mechanisms used in this class of phages we have performed an investigation of the transcriptional pattern during the lytic growth cycle of TP901-1 by hybridizing Northern blots of RNA from infected cells with various regions of the TP901-1 genome. Such transcriptional studies have not previously been performed either on temperate lactococcal phages or on phages belonging to the P335 group. Preliminary dot blot analysis had indicated that the region upstream of the integrase was transcribed early during infection by TP901-1. Since this region is particularly interesting for regulatory reasons in a temperate phage, part of it was also sequenced in the present study and provided the tools for a more detailed transcriptional analysis of the early region as reported below.

\section{METHODS}

Bacteria and phage. The temperate bacteriophage TP901-1 was induced from Lactococcus lactis subsp. cremoris 901-1 (Braun et al., 1989) by the use of UV light as previously described (Christiansen et al., 1994). L. lactis subsp. cremoris 3107 (Braun et al., 1989) was used as host for TP901-1. L. lactis subsp. cremoris ES46 is a derivative of 3107 , lysogenized with TP901-1 (Christiansen et al., 1994). A restriction map of TP901-1 is available (Christiansen et al., 1994). Restriction fragments generated with EcoRI, AccI, BclI, ClaI and EcoRV have been named with numbers in order of decreasing size (for EcoRI see Fig. 1)

Bacterial growth conditions. L. lactis subsp. cremoris 3107 and $901-1$ were grown at $30^{\circ} \mathrm{C}$ without shaking in either M17 medium (Terzaghi \& Sandine, 1975) containing $0.5 \%(\mathrm{w} / \mathrm{v}$ ) glucose (GM17) or in the defined medium SA (Jensen \& Hammer, 1993) supplemented with either $1 \%$ glucose (GSA) or $1 \%$ glucose and $5 \mathrm{mM} \mathrm{CaCl}_{2}\left(\mathrm{GSA}_{\mathrm{Ca}}\right)$. GM17 plates were solidified with $1.5 \%(\mathrm{w} / \mathrm{v}$ ) agar (Difco). Exponentially growing cultures of the L. lactis strains in SA medium were routinely obtained using the following procedure. From a GM17 plate a fresh colony was suspended in GSA (or GSA ${ }_{\mathrm{Ca}}$ ) and a set of dilutions was made. Dilutions were incubated at $30^{\circ} \mathrm{C}$ overnight. Inoculation of cultures used in experiments was performed from a culture with an $\mathrm{OD}_{450}$ not exceeding $1 \cdot 0$. The cultures were gently agitated using a magnetic stirrer to prevent sedimentation of cells.

Preparation of phage for infection. TP901-1 was streaked to single plaques three times on lawns of the host strain L. lactis subsp. cremoris 3107 . One plaque was subsequently inoculated into $10 \mathrm{ml}$ of strain 3107 growing exponentially in GM17. After lysis, cell debris was spun down by centrifugation and the titre of the lysate was determined. A GM17 overnight culture of 3107 was diluted 1:100 and allowed to grow at $30^{\circ} \mathrm{C}$ until the $\mathrm{OD}_{600}$ reached $0 \cdot 15$. The culture was then infected with the above lysate to a final titre of $10^{4}$ p.f.u. $\mathrm{ml}^{-1}$. The culture was incubated at $30^{\circ} \mathrm{C}$ until lysis occurred. EGTA and $\mathrm{MgCl}_{2}$ were added to concentrations of $10 \mathrm{mM}$ and $50 \mathrm{mM}$, respectively. After an additional $8 \mathrm{~h}$ of incubation at $30^{\circ} \mathrm{C}, \mathrm{NaCl}$ was added to a final concentration of $1 \mathrm{M}$. The lysate was then clarified by centrifugation and the phage were precipitated by adding PEG 6000 to a final concentration of $10 \%(w / v)$.

Phage were collected by centrifugation (10000 r.p.m.; Sorvall GSA rotor), resuspended in SM buffer $[100 \mathrm{mM} \mathrm{NaCl}, 10 \mathrm{mM}$ $\mathrm{MgCl}_{2}, 50 \mathrm{mM}$ Tris/ $\mathrm{HCl} \mathrm{pH} \mathrm{7.5,0.01 \% (w/v)} \mathrm{gelatine]} \mathrm{and}$ filtered through a $0.45 \mu \mathrm{m}$ sterile filter.

Isolation of RNA. L. lactis subsp. cremoris 3107 growing exponentially in $\mathrm{GSA}_{\mathrm{Ca}}$ medium at $30^{\circ} \mathrm{C}$ was, at an $\mathrm{OD}_{450}$ of 0.5 , infected with TP901-1 using a m.o.i. of 5. At various time points after infection, $30 \mathrm{ml}$ aliquots were withdrawn and rapidly chilled in liquid nitrogen. Cells were harvested at $0^{\circ} \mathrm{C}$ and pellets were frozen. RNA was subsequently isolated using the method described by Johnsen et al. (1996) with some modifications as follows. On ice, $0.7 \mathrm{~g}$ glass beads $(<100 \mu \mathrm{m}$; Sigma) and $1 \mathrm{ml}$ RNA extraction buffer [ $4 \mathrm{M}$ guanidine thiocyanate, $10 \mathrm{mM}$ MES pH 7.0, $10 \mathrm{mM}$ EDTA, $50 \mathrm{mM}$ $\beta$-mercaptoethanol, $5 \%(\mathrm{v} / \mathrm{v})$ Triton X-100] were added. Samples were then vortexed until thawed. Fifteen to twenty cycles each consisting of $30 \mathrm{~s}$ vortexing and $30 \mathrm{~s}$ cooling on ice, were then performed. A $1 \mathrm{ml}$ aliquot of phenol:chloroform (5:1) $\mathrm{pH} \mathrm{4.7} \mathrm{(Sigma)} \mathrm{was} \mathrm{added} \mathrm{and} \mathrm{samples} \mathrm{were} \mathrm{vortexed}$ for $10 \mathrm{~s}$ and frozen at $-80^{\circ} \mathrm{C}$. Subsequently, samples were placed on ice and vortexed for 10 s periods until thawed. After centrifugation (10 min at 10000 r.p.m.; Sorvall SS34 rotor), the aqueous phase was removed and extracted twice with $1 \mathrm{ml}$ phenol: chloroform $(5: 1) \mathrm{pH} 4 \cdot 7$. RNA was precipitated with a $1 / 10$ vol. $3 \mathrm{M}$ sodium acetate and a 2.5 vol. $96 \%$ (w/v) ethanol. RNA was resuspended in TE buffer (10 $\mathrm{mM}$ Tris/ $\mathrm{HCl} \mathrm{pH} \mathrm{8.0,1} \mathrm{mM}$ EDTA). RNA concentration was estimated spectrophotometrically at $260 \mathrm{~nm}$. One $A_{260}$ unit equals $40 \mu \mathrm{g}$ RNA $\mu \mathrm{l}^{-1}$.

Sequencing. Sequence determination was performed on both strands of the plasmids pG7f6 and pG5f4 (Christiansen $e t$ al., 1994) containing EcoRI fragment 6 and EcoRV fragment 4 , respectively, by the Sanger method of dideoxy-mediated chain termination (Sanger et al., 1977) using the sequencing kit from USB Biochemicals version 2.0 The overlaps between EcoRI fragment 7 and EcoRI fragments 6 and 2, respectively, were thus determined by sequencing of the EcoRV fragment 4 .

Northern blotting. Aliquots $(10 \mu \mathrm{g})$ of total RNA were incubated for $10 \mathrm{~min}$ at $70^{\circ} \mathrm{C}$ in $50 \%(\mathrm{v} / \mathrm{v})$ deionized formamide, $2.5 \mathrm{M}$ formaldehyde, $0.1 \mathrm{mg}$ ethidium bromide $\mathrm{ml}^{-1}$ and $1 \times$ MOPS buffer (40 mM MOPS, $10 \mathrm{mM}$ sodium acetate, $1 \mathrm{mM}$ EDTA, $\mathrm{pH}$ 7) prior to electrophoresis on $1 \%$ (w/v) agarose gels containing $0.75 \mathrm{M}$ formaldehyde. Gel and electrophoresis solutions were buffered with $1 \times$ MOPS 
Table 1. Description of probes used for Northern hybridization

A graphical presentation of the probes aligned with the restriction map is given in Fig. 1.

\begin{tabular}{|c|c|c|c|}
\hline Name & Size (bp) & Coordinates $^{*}$ & Description \\
\hline A & 1924 & $4470-6394$ & EcoRI fragment 6 of TP901-1 \\
\hline B & 202 & $3401-3603$ & $\begin{array}{l}\text { PCR on TP901-1 (UV-induced) DNA using } \\
\text { primers } 65 \text { and Rerm } 2\end{array}$ \\
\hline $\mathrm{C}$ & 258 & $5064-5322$ & $\begin{array}{l}\text { PCR on TP901-1 (UV-induced) DNA using } \\
\text { primers T764 and T542 }\end{array}$ \\
\hline $\mathrm{D}$ & 310 & $2848-3158$ & $\begin{array}{l}\text { PCR on TP901-1 (UV-induced) DNA using } \\
\text { primers Erm } 3 \text { and } 22\end{array}$ \\
\hline $\mathrm{E}$ & 1600 & $-\dagger$ & EcoRV fragment 8 of TP901-1 \\
\hline $\mathrm{F}$ & 8400 & $-\dagger$ & EcoRV fragment 1 of TP901-1 \\
\hline
\end{tabular}

* Sequence coordinates given in Fig. 1 and EMBL entry Y14232.

†Probe is outside the sequenced region.

(a)
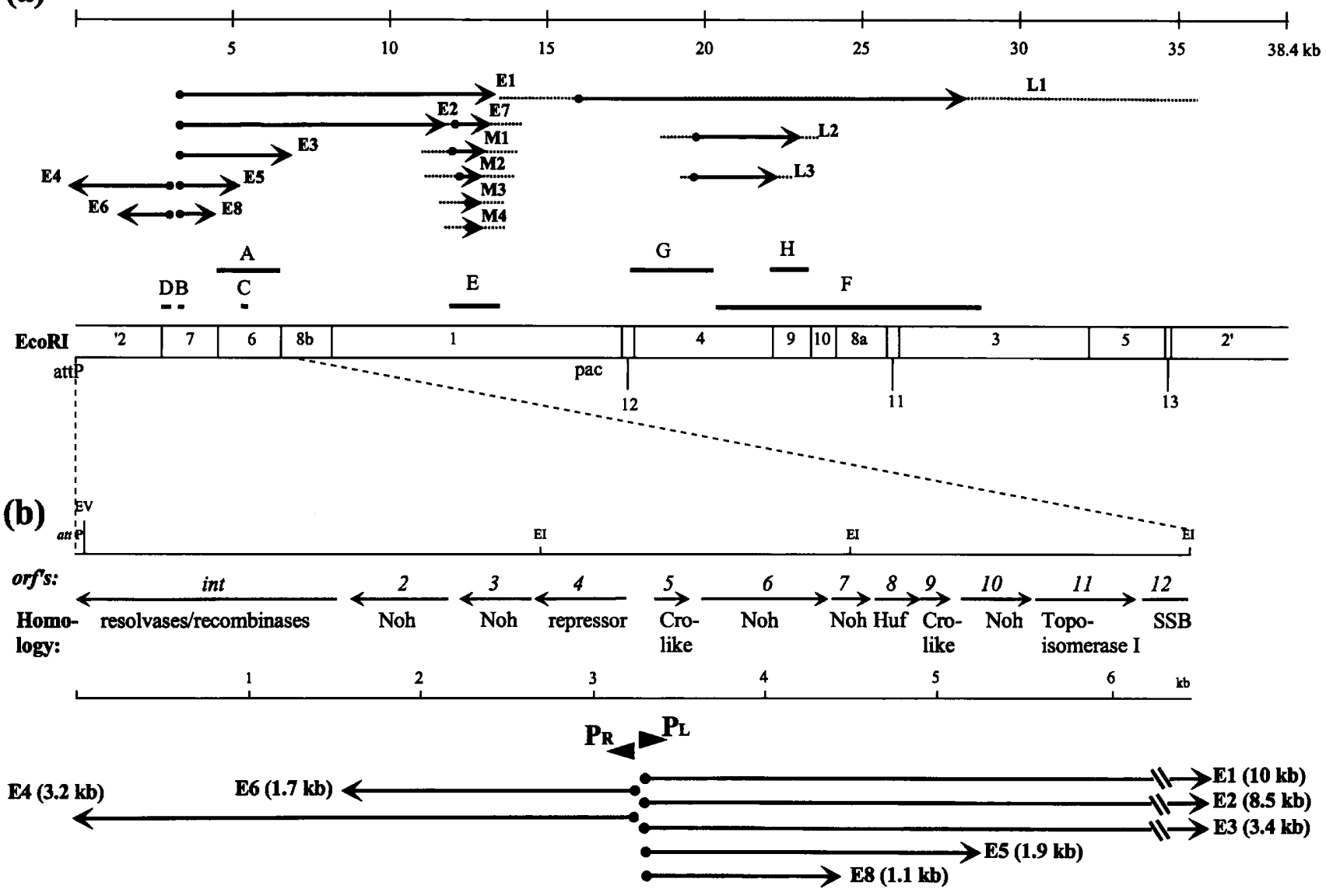

Fig. 1. Schematic presentation of the temporal transcription of TP901-1. The figure is drawn to scale. (a) Alignment of the observed transcripts with the EcoRI restriction map of TP901-1. Arrows indicate positions of the observed transcripts. The name of each transcript is stated at the end of the arrow. Black bars represent the probes used in the Northern blot hybridizations. The ECORI fragments are numbered according to the nomenclature of Christiansen et al. (1994). (b) Position and orientation of the ORFs derived from the sequence. Upper arrows indicate the ORFs. The name of each ORF is stated above the arrows and the observed homology of each ORF is indicated below (for more details see Table 2 and text). Noh, no observed homology; Huf, homology to protein with unknown function. The promoters $P_{L}$ and $P_{R}$ are marked with black triangles. Arrows at the bottom of the figure represent the early transcripts. The name and size of each transcript is marked at the end of the arrow. 
Table 2. Features of ORF4-ORF12 of phage TP901-1

\begin{tabular}{|c|c|c|c|c|c|c|}
\hline Name & $\begin{array}{l}\text { Putative ribosome-binding site (in } \\
\text { bold) and start codon (underlined) }\end{array}$ & $\begin{array}{l}\text { Predicted } \\
\text { start } \\
\text { position }\end{array}$ & $\begin{array}{l}\text { Predicted } \\
\text { stop } \\
\text { position }\end{array}$ & $\begin{array}{l}\text { Intergenic } \\
\text { distance (nt) }\end{array}$ & $\begin{array}{l}\text { Size of } \\
\text { ORF (aa) }\end{array}$ & Homology \\
\hline ORF4 & AAAAAAGAGGTTTTT $\underline{\text { ATG }}$ & 3188 & 2646 & & 180 & $\begin{array}{l}\text { Local homology to } \\
\text { lactococcal phage } \\
\text { repressors (see Fig. 2) }\end{array}$ \\
\hline ORF5 & AGAAAGGAGAAACATAAATG & 3357 & 3575 & 168 & 72 & $\begin{array}{l}\text { Putative Cro-like protein } \\
\text { from the temperate } S \text {. } \\
\text { thermophilus phage } \\
\phi \text { Sfi } 21\end{array}$ \\
\hline ORF6 & AGAAAGGATTCAAAA $\underline{\text { ATG }}$ & 3612 & 4355 & 39 & 247 & No observed homology \\
\hline ORF7 & AGAAAGGAAAGCAC $\underline{\text { ATG }}$ & 4368 & 4562 & 15 & 64 & No observed homology \\
\hline ORF8 & AGAAAGATTAACAGCT $\underline{\text { ATG }}$ & 4627 & 4875 & 67 & 82 & $\begin{array}{l}\text { ORF7 of r1t }(100 \% \\
\text { identity); local homology } \\
\text { to C- and N-terminal } \\
\text { ORF80 of L. lactis phage } \\
\text { BK5-T }\end{array}$ \\
\hline ORF9 & AAGTTGGCGGTGATGAAATG & 4872 & 5048 & -1 & 58 & $\begin{array}{l}\text { ORF8 of r1t ( } 94 \% \\
\text { identity); putative Cro- } \\
\text { like protein of L. lactis } \\
\text { phage BK5-T ( } 58 \% \\
\text { identity) }\end{array}$ \\
\hline ORF10 & GAAATGGAGAATTTAA ATG & 5147 & 5536 & 101 & 129 & No observed homology \\
\hline ORF11 & ATGCGTGAGGTAAATC $\underline{\overline{\mathrm{ATG}}}$ & 5545 & 6168 & 11 & 207 & $\begin{array}{l}\text { DNA topoisomerase I of } \\
\text { two Mycoplasma species }\end{array}$ \\
\hline ORF12 & AGATTGGAGTAAATA ATG & 6168 & - & 2 & - & $\begin{array}{l}\text { GP36 of B. subtilis phage } \\
\text { SPP1; prokaryotic single- } \\
\text { stranded DNA-binding } \\
\text { proteins }\end{array}$ \\
\hline
\end{tabular}

buffer. Gels were subsequently blotted onto Genescreen + membranes (Du Pont) by capillary transfer (Sambrook et al., 1989).

RNA standard markers $(0.24 \mathrm{~kb}-9.5 \mathrm{~kb}$; Gibco-BRL) were loaded on each gel and used for estimation of transcript sizes. For transcripts larger than $9.5 \mathrm{~kb}$ a semi-logarithmic extrapolation was made.

Phage DNA. Phage DNA was prepared as described by Sambrook et al. (1989).

Preparation of DNA probes and hybridization conditions. Probes used in Northern analysis are described in Table 1 and the position of the probes compared to the restriction map of TP901-1 is shown in Fig. 1. DNA of probes A, E and F was purified from recombinant plasmids containing only the relevant DNA fragment. DNA of probes $B, C$ and $D$ was synthesized by PCR on TP901-1 DNA, followed by purification of the PCR product on an agarose gel. Probes were labelled with $\left[\alpha_{-}{ }^{32} \mathrm{P}\right] \mathrm{dATP}$ using a random primed DNA labelling kit (Boehringer Manheim). Probes were hybridized to Northern blots in $0.5 \mathrm{M}$ sodium phosphate buffer $\mathrm{pH} 7.2$ containing $7 \%(\mathrm{w} / \mathrm{v})$ SDS at $65^{\circ} \mathrm{C}$ for at least $16 \mathrm{~h}$. Subsequently, membranes were washed three times in $20 \mathrm{mM}$ sodium phosphate buffer $\mathrm{pH} 7 \cdot 2$ containing $1 \% \mathrm{SDS}$ at $65^{\circ} \mathrm{C}$ for $15 \mathrm{~min}$ each.

Primer extension transcript mapping. Primer PE2, 5' AGACACAGTTCTCTCTGAAAGCCCC $3^{\prime}$ (nt 3458-3434 in EMBL entry Y14232) was phosphorylated using T4 poly- nucleotide kinase (Gibco BRL) and $\left[{ }^{32} \mathrm{P}\right] \mathrm{ATP}$ (Amersham) as described by Sambrook et al. (1989).

Total RNA $(25 \mu \mathrm{g})$ isolated from $L$. lactis subsp. cremoris 3107 infected with TP901-1 was mixed with 1 pmol phosphorylated primer PE2 in a volume of $10 \mu \mathrm{l}$ and incubated at $70^{\circ} \mathrm{C}$ for $10 \mathrm{~min}$. The mixture was allowed to cool to $37^{\circ} \mathrm{C}$ over a $1 \mathrm{~h}$ period. Superscript reverse transcriptase (Gibco; $1 \mu \mathrm{l}$ ), $5 \times$ first-strand buffer (Gibco; $4 \mu \mathrm{l}$ ), 0.1 M DTT (Gibco, $2 \mu \mathrm{l})$ and dATP, dGTP, dCTP and dTTP to a final concentration of $500 \mu \mathrm{M}$ were subsequently added and the mixture was incubated at $37^{\circ} \mathrm{C}$ for $1 \mathrm{~h}$. The primer extension product was electrophoresed next to a DNA sequencing reaction using phosphorylated end-labelled primer PE2.

Primers. DNA probes made by PCR (see Table 1) were generated using the following oligonucleotides: 65 , CCTTTCTAGTTCTAGTT; 22, GCAGTATCTAAGACAAC; Rerm2, GTGTGGAACTCAGTATA; Erm3, CAGATCATGGCTGAAAG; T764, CACGCAGAGCAAGTAGG; T542, TGACCTTCATCAAGCCG.

\section{RESULTS}

\section{Analysis of the DNA sequence of EcoRI fragments 6 and 7}

A map of the TP901-1 phage genome of $38.4 \mathrm{~kb}$ is shown in Fig. 1. A region of $2 \cdot 8 \mathrm{~kb}$ of the EcoRI fragment 2 containing the phage TP901-1 attachment site attP, and 


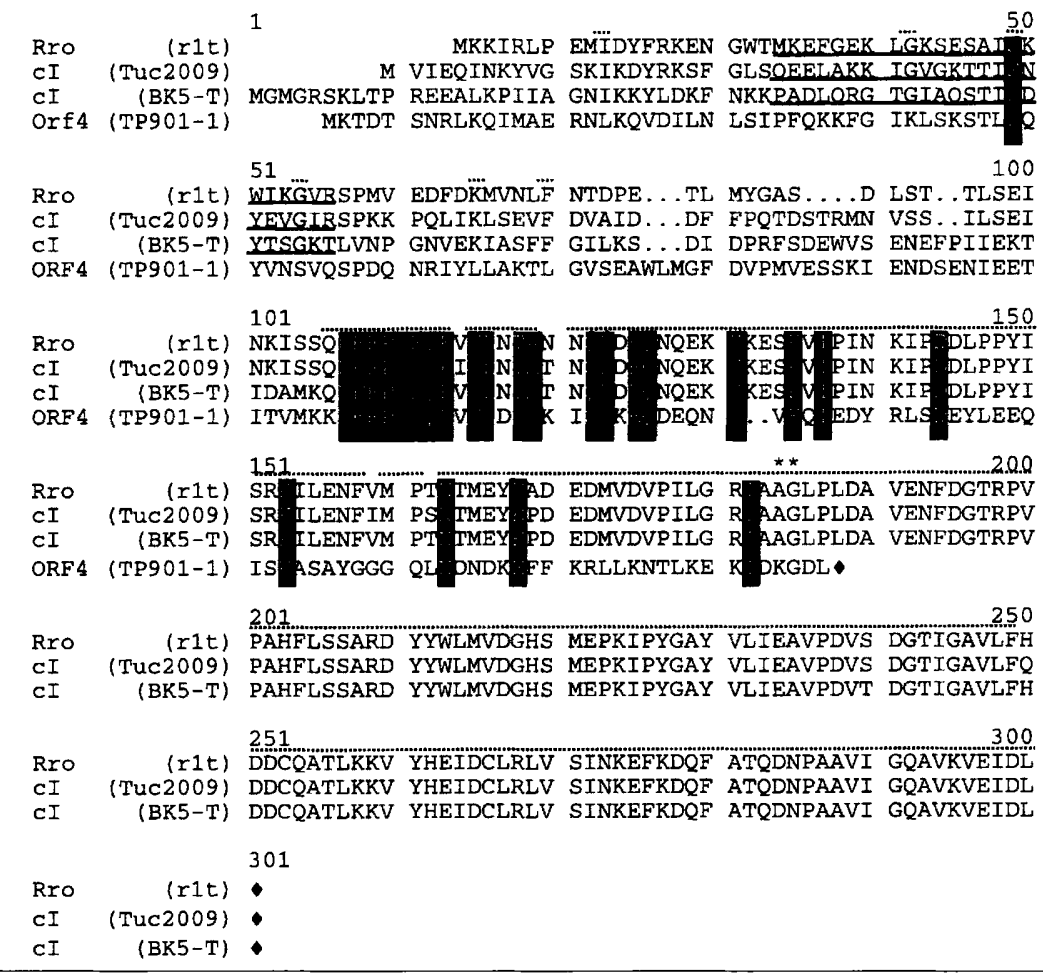

Fig. 2. Alignment of ORF4 with repressors of the lactococcal phages r1t (Rro), Tuc2009 (cl) and BK5-T (cl). Amino acids identical in all four ORFs are shown on a black background. Asterisks and the underlined region indicate the RecA-induced cleavage site and helix-turn-helix motif, respectively, as suggested by van Sinderen et al. (1996), van de Guchte et al. (1996b) and Boyce et al. (1995a). The identical C termini of the Rro and $\mathrm{Cl}$ proteins are marked by a dotted line. Black diamonds mark the positions of stop codons. orf1 (encoding the integrase), orf 2 and orf 3 has previously been sequenced (Christiansen et al., 1996).

Dot blot analysis had indicated that the region upstream of int was transcribed early during phage infection (Madsen, 1996). To improve the basis for a transcriptional map of TP901-1 with detailed investigations of the early transcribed region, we decided first to sequence the upstream-located EcoRI fragments 6 and 7, consisting of $3691 \mathrm{bp}$. This DNA sequence was combined with the previously sequenced region and we introduced a numbering system starting with the last base pair in the core region (TCAAT) as number 1 . The first nucleotides in the new upper strand from position 1 to 5 are thus ATTGA. Since the crossover event between the phage genome and the bacterial genome occurs in the core region, the integrated phage genome will thus be numbered from 1 to approximately 38400 counting from att $R$ to att $L$. In our previous paper we introduced numbering of the ORFs in the same direction starting with orf1, encoding the integrase, being located closest to attR (Christiansen et al., 1996).

Nine putative ORFs, designated orf4-orf12, could be derived from the new DNA sequence. orf 4 has the same orientation as the phage integrase gene and the two upstream-located ORFs (orf1-orf3), whilst the remaining ORFs are orientated in the opposite direction, rightwards, as shown in Fig. 1. Analysis of the sequence using the Genemark algorithm (Borodovsky \& McIninch, 1993) revealed that the nine ORFs showed normal codon usage and were therefore likely to encode lactococcal proteins, the only exception being the first 37 codons of orf4 (position 3299-3188). A proper ribosome- binding site sequence showing considerable similarity to the consensus ribosome-binding site identified for $L$. lactis species (Ludwig et al., 1985) precedes the shorter version, which is not the case for the ORF initiating at position 3299. orf4 is therefore believed to start at position 3188 and encode a protein with a length of 180 aa (Table 2). Putative ribosome-binding sites were identified for the rest of the ORFs except for orf9. The orf 9 upstream region has less similarity to the ribosomebinding site consensus but the start codon of orf 9 overlaps with the stop codon of orf 8 . orf 9 might therefore also be expressed by translational coupling. The positions of the start and stop codons, the size of the ORFs and the intergenic distances between the ORFs are summarized in Table 2.

The nine ORFs were analysed for homology to other proteins using the GCG software package (Devereux $e t$ al., 1984). ORF4 shows local homology to the repressor Rro from the lactococcal phage r1t (van Sinderen et al., 1996; Nauta et al., 1996), as well as the suggested repressors from the lactococcal phages Tuc2009 (van de Guchte et al., 1994b) and BK5-T (Boyce et al., 1995a). A similarity of $75 \%$ was found between ORF4 from TP901-1 and the three phage repressors over a stretch of 20 aa (Fig. 2). ORF5 shows homology to ORF5 from the temperate Streptococcus thermophilus phage $\phi \mathrm{Sfi} 21$ (Bruttin et al., 1997) with $24 \%$ identity and $43 \%$ similarity. Based on the genetic organization of $\phi \mathrm{Sfi} 21$, ORF5 has been proposed to function as a Cro-like protein. Considerable homology was found between ORF4 and ORF5 of TP901-1 and ORF4 and ORF5 of the temperate $S$. thermophilus bacteriophage $\phi \mathrm{O} 1205$ (48 and $47 \%$ identity, respectively). However nothing 


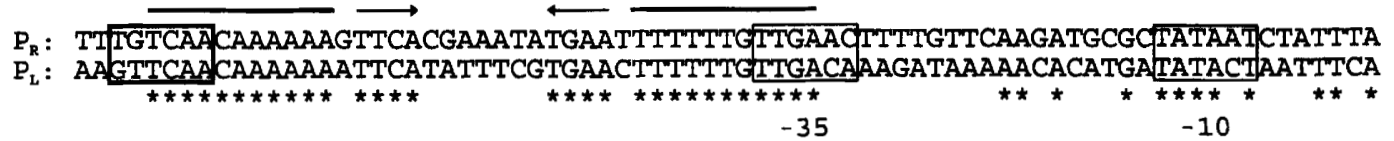

Fig. 3. Alignment of the sequences of the $P_{R}$ and $P_{L}$ promoters. Sequence from position 3286 to 3212 in the case of $P_{R}$ and from position 3240 to 3314 in the case of $P_{L}$ is shown. The -35 and -10 promoter sequences are marked by open boxes. The -35 region from the divergent promoter is indicated with a bold-outlined box. Identical bases in the two promoter sequences are marked with asterisks. Arrows indicate the inverted repeat observed in the region between $P_{L}$ and $P_{R}$.

has yet been published about $\phi \mathrm{O} 1205$ (GenBank accession number U88974). The genetic organization of orf4 and orf5 is identical between TP901-1 and $\phi \mathrm{O} 1205$, orf4 being the first ORF in a tetracistronic gene cluster and orf5 being the first ORF of a large cluster of divergently orientated ORFs.

ORF8 of TP901-1, which has a size of 82 aa, was found to be $100 \%$ identical to ORF7 of r1t. Furthermore, ORF8 shows homology to the 80 -aa-long ORF80 from the temperate lactococcal phage BK5-T. This homology was concentrated in the $\mathrm{N}$ terminus $(45 \%$ similarity in a 24 aa region) and in the $\mathrm{C}$ terminus ( $70 \%$ similarity in a 10 aa region). The functions of ORF7 of $r 1 t$ and ORF80 of BK5-T are unknown. ORF9 of TP901-1 shows homology to ORF8 of r1t (94\% identity) and to ORF63 of BK5-T (39\% similarity overall). ORF63 of BK5-T has been suggested to have a function analogous to that of Cro in phage $\lambda$ (Boyce et al., 1995a). ORF 11 shows a low degree of similarity to topoisomerase I from two different species of Mycoplasma (28 and $31 \%$ identity) (Fraser et al., 1995; Himmelreich et al., 1996). ORF12 shows homology to a number of prokaryotic singlestranded DNA-binding proteins. Furthermore, $38 \%$ similarity was found between ORF12 and GP36 from the Bacillus subtilis phage SPP1 (Pedré et al., 1994). GP36 is required for initiation of DNA replication of SSP1. The remaining three ORFs (ORF6, ORF7 and ORF10) revealed no similarity to known sequences.

Using the profile scan program from the GCG software package, the nine ORFs were scanned for protein motifs. ORF5 was found to contain a helix-turn-helix motif from $\mathrm{Gln} 19$ to Asn 38 in the $\mathrm{N}$-terminal part of the protein. None of the other ORFs were predicted to contain any protein motifs.

The sequence was analysed for promoter elements and in the orf4-orf5 intergenic region two putative promoters were found, orientated in the right- and leftward directions. The -35 sequences of the two promoters are separated by only $31 \mathrm{bp}$ and the region between the two promoters contains an inverted repeat. Thus, the sequences upstream of the promoters are highly homologous (Fig. 3). The promoter reading towards the integrase was designated $P_{R}$ for promoter used for establishment of life cycle characterized by an almost totally repressed phage genome, whilst the promoter pointing rightwards (Fig. 1) was designated $P_{L}$ for promoter used for the lytic life cycle, as shown below by Northern analysis.

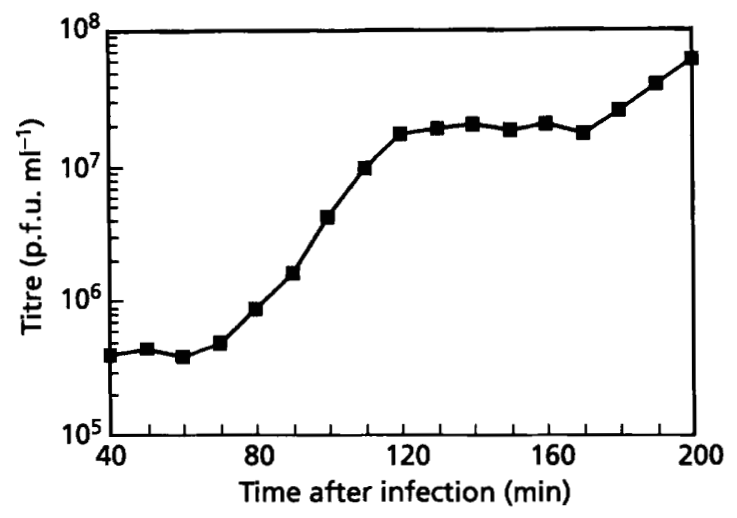

Fig. 4. One-step growth of TP901-1 on L. lactis subsp. cremoris 3107. Strain 3107 growing exponentially in $\mathrm{GSA}_{\mathrm{Ca}}$ was infected at $O D_{450} 0.1$ with a m.o.i. of 0.005 . Adsorption of phage was allowed for $5 \mathrm{~min}$ prior to a 1000-fold dilution of the culture in prewarmed $\mathrm{GSA}_{\mathrm{Ca}}$. Numbers of infective centres was subsequently determined as a function of time. Time 0 is the time at which infection occurred.

The sequence was analysed for the existence of putative transcriptional terminators. No sequences constituting a putative rho-independent terminator were found.

\section{One-step growth of TP901-1}

To design the experiments for determination of the temporal pattern of transcription, the one-step growth kinetics of TP901-1 was determined. An exponentially growing culture of $L$. lactis subsp. cremoris 3107 in $\mathrm{GSA}_{\mathrm{Ca}}$ medium was infected with a m.o.i. of 0.005 and phage were allowed to adsorb for a period of $5 \mathrm{~min}$. Subsequently, the culture was diluted 1000 -fold in prewarmed $\mathrm{GSA}_{\mathrm{Ca}}$ medium. In this way, the concentration of phage and bacteria was lowered and the probability of infection by unadsorbed phages was decreased. The phage titre in the diluted culture was determined as a function of time (Fig. 4). The phage titre started to rise $65 \mathrm{~min}$ after infection, indicating a latent period of $65 \mathrm{~min}$ for TP901-1. By assuming a Poisson distribution of phage particles on host cells it can be calculated that the number of cells infected with more than one phage is less than $1 \%$ of the total number of infected cells. Consequently, the burst size could be determined as the ratio between the phage titre levels before and after the burst. Major variations in burst size were observed between separate experiments, whereas 


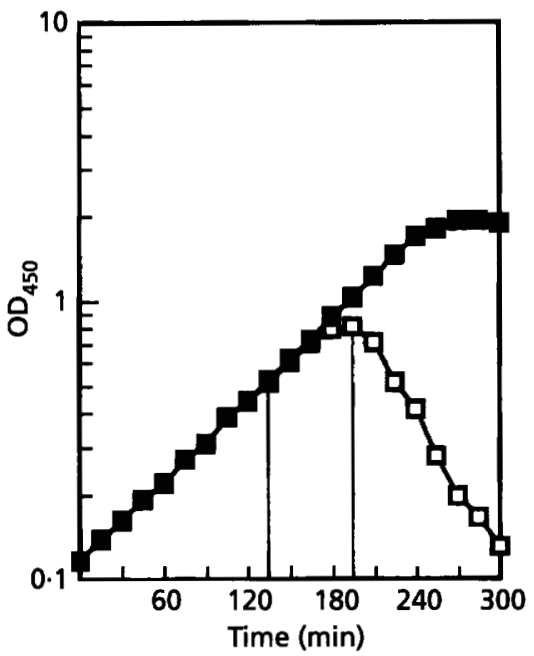

Fig. 5. Growth of L. lactis subsp. cremoris 3107 infected with TP901-1 at $O_{450} 0.5$ using a m.o.i. of 5 ( $\square$ ). Growth of uninfected 3107 was also followed $(\square)$. Time 0 is the time at which strain 3107 was inoculated into GSA $_{c_{a}}$ medium from an exponentially growing $\mathrm{GSA}_{\mathrm{c}_{a}}$ culture. The vertical line at $135 \mathrm{~min}$ indicates time of infection with TP901-1; the second vertical line at $195 \mathrm{~min}$ indicates start of lysis.

the latent period was very stable. From six independent experiments in $\mathrm{GSA}_{\mathrm{Ca}}$ medium the mean burst size was calculated to be $40 \pm 10$. Other lactococcal phages have latent periods of $40-60 \mathrm{~min}$, with burst sizes ranging from 10 to 400 (Keogh, 1973; Klaenhammer, 1984; Moineau et al., 1992; Beresford et al., 1993; Lillehaug et al., 1991). The latent period of TP901-1 was $65 \mathrm{~min}$ in both GSA ${ }_{\mathrm{Ca}}$ and GM17 medium (data not shown), even though the growth rates of strain 3107 in the two media are slightly different (Jensen \& Hammer, 1993). The defined $\mathrm{GSA}_{\mathrm{Ca}}$ medium was used for further experiments.

Infection of 3107 with TP901-1 using a high m.o.i. was also examined. Again assuming a Poisson distribution of phage particles on bacteria, it can be calculated that, using a m.o.i. of 5 , the number of uninfected cells is less than $1 \%$ of the total number of cells. At an $\mathrm{OD}_{450}$ of 0.5 , a culture of 3107 growing exponentially in $\mathrm{GSA}_{\mathrm{Ca}}$ medium was infected with TP901-1 using a m.o.i. of 5 and $\mathrm{OD}_{450}$ was determined as a function of time (Fig. 5). The growth rate of 3107 was unchanged for the first $30 \mathrm{~min}$ after infection. Subsequently, the growth rate started to decrease and $65 \mathrm{~min}$ after infection, at an $\mathrm{OD}_{450}$ of approximately $0 \cdot 8$, the culture started to lyse. The lysis of 3107 was not immediate. The time from the start of cell lysis until $\mathrm{OD}_{450}$ reached $0 \cdot 1$ was $120 \mathrm{~min}$.

\section{Analysis of the early transcribed region}

For the mRNA analysis the high m.o.i. of 5 was used. At various time points after infection aliquots were withdrawn and total RNA was extracted. Northern blots of these RNA samples were hybridized with DNA probes from different regions of the putative early transcribed region of TP901-1. EcoRI fragment 6 (probe A) hybridized to four transcripts (Fig. 6a). By use of standard RNA markers, these transcripts were estimated to be 10 (E1), 8.5 (E2), 3.4 (E3) and 1.9 (E5) kb in size. To further map the positions of the transcripts, hybridizations with probes $B, C$ and D were performed. Probes $B$ and D are located immediately to each side of the divergent promoter region suggested from the sequence analysis. Probe $\mathrm{C}$ is a smaller probe located within probe $\mathrm{A}$. Using probe $\mathrm{B}$, hybridization to the same transcripts, E1, E2, $\mathrm{E} 3$ and E5, was observed in addition to a transcript of $1 \cdot 1 \mathrm{~kb}$ (E8) (Fig. 6b). This implies that the E8 transcript is located to the left of probe A, given the orientation in Fig. 1. Probe $\mathrm{C}$ hybridized to the E1, E2 and E3 transcripts (Fig. 6c). This implies that the E5 transcript is located to the left of probe $\mathrm{C}$, given the orientation in Fig. 1. As expected, hybridization with probe $\mathrm{D}$ revealed transcripts of sizes different from those observed with probes A, B and C. Two transcripts with sizes of 3.2 (E4) and $1 \cdot 7$ (E6) kb were observed using probe $D$ (Fig. 6d). The orientation of ORFs 2-12 strongly suggests that the region between probes $\mathrm{B}$ and $\mathrm{D}$ contains divergent promoters.

The seven transcripts observed using the probes A-D did not follow exactly the same kinetics. All transcripts accumulated during the first $10 \mathrm{~min}$, but whereas the amounts of E1, E2, E3, E4, E6 and E8 then decreased, the amount of $\mathrm{E} 5$ remained at the same level from $10 \mathrm{~min}$ and throughout the rest of the infection cycle. We define E1-E6 and E8 as the early class of transcripts, i.e. those present at maximum levels $10 \mathrm{~min}$ after infection.

\section{Analysis of middle and late expressed regions}

Samples for RNA analysis were obtained as before. Probe E, the $1.6 \mathrm{~kb}$ EcoRV fragment 8, was chosen for the transcript analysis since it was supposed to cover the distal end of the 10-kb-long E1 transcript and possibly also later-occurring transcripts. As shown in Fig. 6(e) the $10 \mathrm{~kb}$ E1 transcript was observed as well as five new transcripts ranging in size from 0.3 to $1.5 \mathrm{~kb}$. Like E1, the $1.5 \mathrm{~kb}$ transcript peaked at $10 \mathrm{~min}$. It was therefore defined as an early transcript and named E7, even though a transcript of this size is seen thoughout the rest of the infection cycle. The four remaining transcripts were present in low amounts from 1 to $20 \mathrm{~min}$ after infection, but at $30 \mathrm{~min}$ a dramatic increase in the amounts of all four of them was observed and the levels were high throughout the rest of the infection cycle. These transcripts, designated the middle transcripts (M1-M4), constitute a new class of transcripts, occurring after the early transcripts but before the late transcripts (Fig. 6e compared with Fig. 6f).

As a probe for late mRNA, the EcoRV fragment 1 (probe F) was used, since genes encoding the major components of the virion particle are located in this region (Johnsen et al., 1995, 1996). Two strong and distinct bands were observed corresponding to transcripts of 3.7 (L2) and 2.7 (L3) kb in size (Fig. 6f). 
(a)

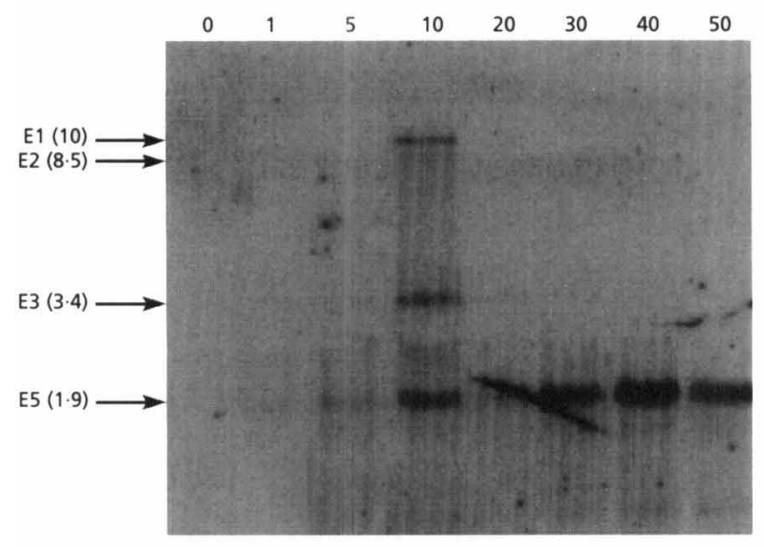

(c)

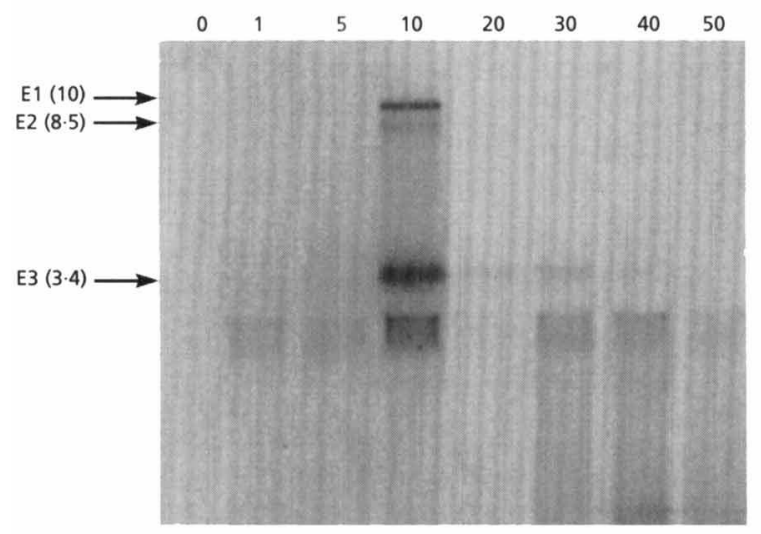

(e)

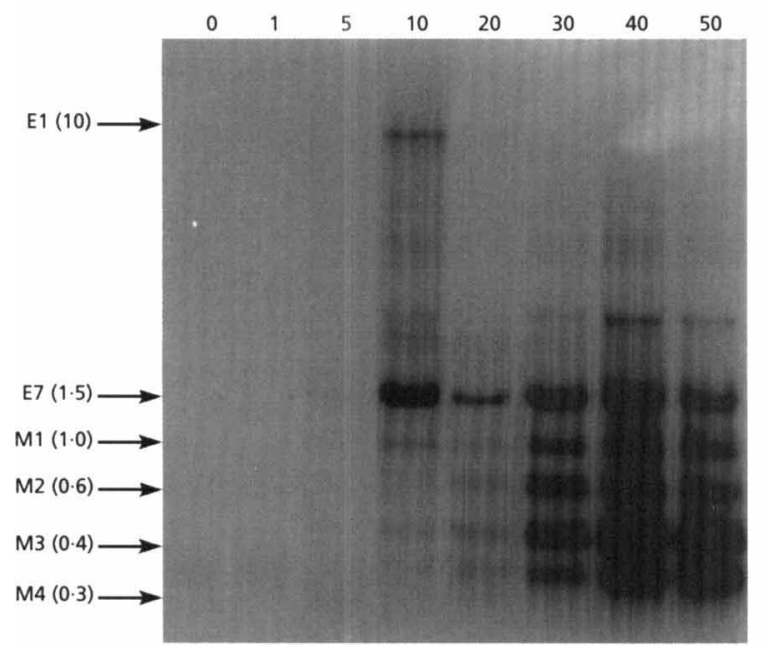

(b)

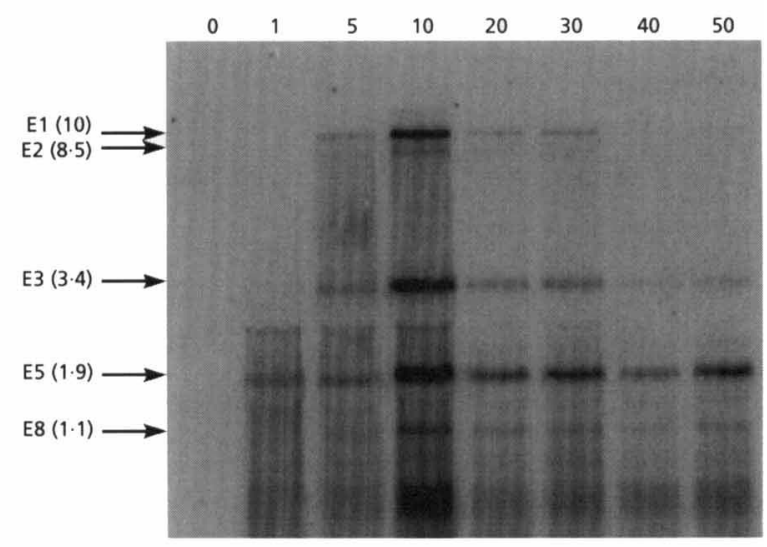

(d)

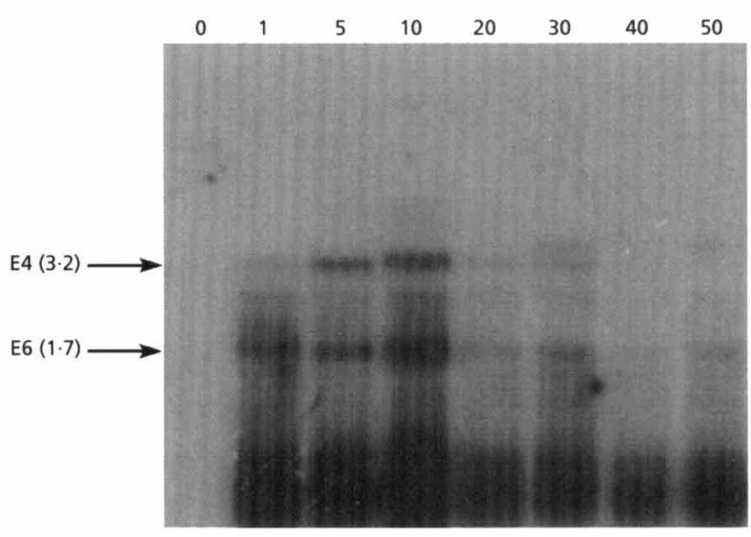

(f)

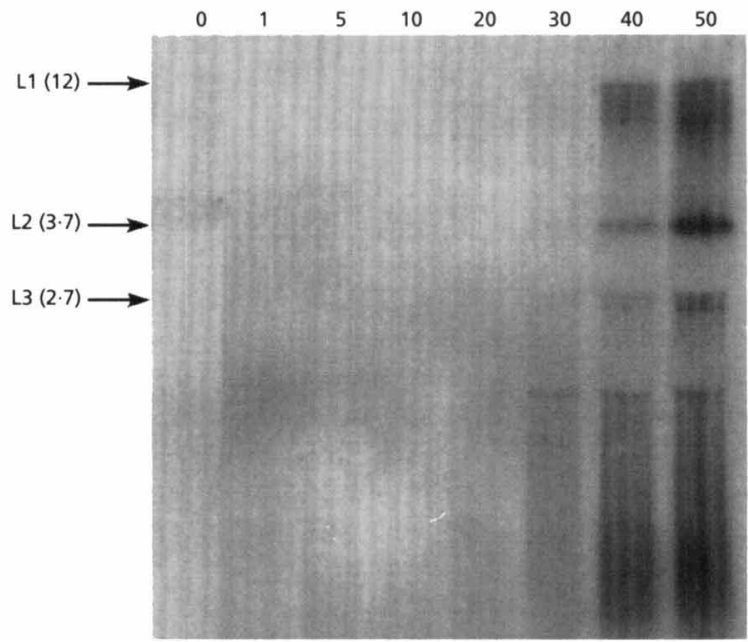

Fig. 6. Northern blot of total RNA isolated from L. lactis subsp. cremoris 3107 at various time points after infection with TP901-1. Numbers above each lane indicate the time after infection in min when the sample was harvested. Aliquots of RNA $(10 \mu \mathrm{g})$ were electrophoresed on a formaldehyde-containing agarose gel and transferred to membranes. Hybridization was performed using probes A-F in (a)-(f), respectively. Positions of the probes aligned with the TP901-1 genome are shown in Fig. 1. A detailed description of the probes is given in Table 1. Arrows on the left of each blot indicate the names and sizes (in $\mathrm{kb}$ ) of the observed transcripts as judged from RNA standard markers (not shown). The sample at time 0 was taken immediately prior to infection. 


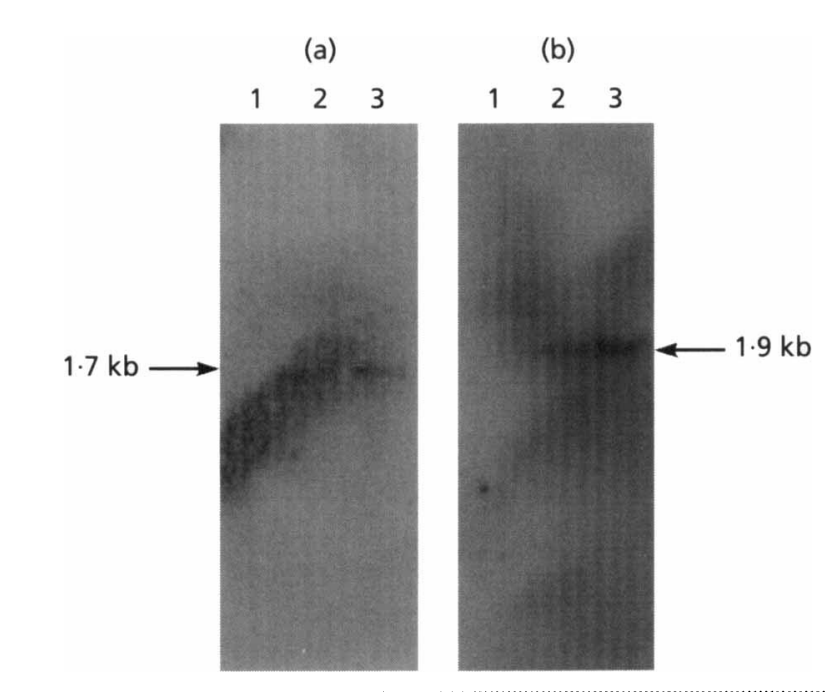

Fig. 7. Northern blot of total RNA isolated from L. lactis subsp. cremoris strains 3107 (lane 1), 901-1 (lane 2) and ES46 (lane 3). Strain 3107 does not contain the prophage of TP901-1, in contrast to 901-1 and ES46. RNA was isolated from cells growing exponentially in GSA. Hybridization was performed using probes $D(a)$ and $B(b)$. Arrows at the sides of the blots indicate positions and sizes of the observed transcripts as judged from RNA standard markers (not shown).

Additionally, hybridization to a large transcript of approximately $12 \mathrm{~kb}$ was seen (L1). This hybridization was however weak and the band observed was very diffuse, indicating processing or degradation of the transcript. Johnsen et al. (1996) also analysed for transcripts in this region using the probes $\mathrm{H}$ and $\mathrm{G}$ (Fig. 1) and found the same major transcripts; the weak signal from L1 was however ignored. L1, L2 and L3 all appear from $40 \mathrm{~min}$ after infection and onwards and were defined as late transcripts (Johnsen et al., 1996).

\section{Transcript analysis in lysogenic bacteria}

Two independent lysogens of TP901-1 were used for the analysis, L. lactis subsp. cremoris 901-1, the parent strain used for isolation of the phage, and strain ES46, a lysogenized derivative of L. lactis subsp. cremoris 3107 . The parent strain 3107 served as the non-lysogenic control. The results of the Northern analysis using probes $B$ and $D$ demonstrated the presence of two different mRNAs each hybridizing to either $B$ or $D$ as shown in Fig. 7. No signals were observed from the nonlysogenic parent strain. The observed transcripts are therefore specific for the phage. Estimated from patterns of hybridization and sizes of 1.9 and $1.7 \mathrm{~kb}$, the mRNAs seem to correspond to the early transcripts E5 and E6, respectively.

\section{Identification of the $P_{L}$ promoter}

Primer extension analysis was performed using RNA isolated after 10 and 50 min of infection. As shown in Fig. 8, a strong signal was observed at $10 \mathrm{~min}$ cor-

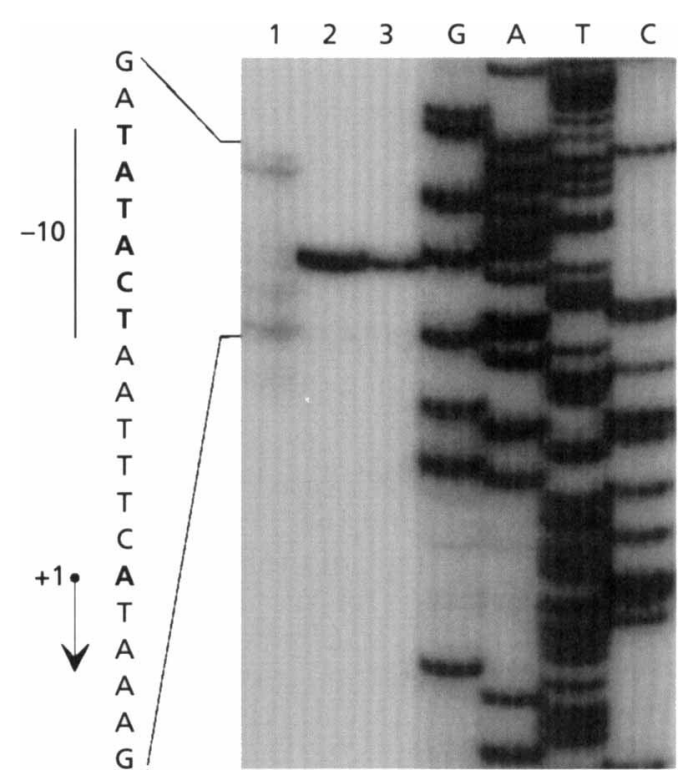

Fig. 8. Primer extension mapping of the $P_{L}$ promoter. Electrophoretic separations of extension products and dideoxy nucleotide sequencing products using the phosphorylated endlabelled primer PE2. Extension reactions were performed on RNA isolated from L. lactis subsp. cremoris 3107 (lane 1), 3107 $10 \mathrm{~min}$ after infection with TP901-1 (lane 2) and $310750 \mathrm{~min}$ after infection with TP901-1 (lane 3). Lanes G, A, T and C contain the four dideoxy nucleotide sequencing products. Sense-strand sequence immediately flanking the transcription start is shown on the left. The Pribnow box and transcription start of $P_{L}$ are marked with -10 and +1 , respectively. +1 corresponds to nucleotide 3314 in the EMBL entry Y14232.

responding to a start at the $\mathrm{A}$ in position 3314 of the sequence in EMBL entry Y14323. This $\mathrm{A}$ is the last nucleotide shown in the promoter sequence in Fig. 3, and as it is localized at a distance of $6 \mathrm{bp}$ from the proposed -10 region, this identifies $P_{L}$ as the promoter used for the early transcripts E1, E2, E3, E5 and E8. The signal from the primer extension was still present at 50 min after infection, in accordance with the presence of significant amounts of E5 at this time (Fig. 6b).

$P_{R}$ could not be identified using the same mRNA samples from the lytic infection. However, when the promoter region was cloned in $L$. lactis, primer extensions identified the corresponding $\mathrm{A}$ in $\mathrm{P}_{\mathbf{R}}$ as the mRNA start (position 3212, results not shown).

\section{DISCUSSION}

\section{Temporal transcription of TP901-1}

The transcriptional analysis performed with TP901-1 identified clusters of early, middle and late transcribed genes and identified the following candidates for regions of gene regulation: the early promoters between orf 4 and orf5, a middle promoter region around position 10000 in the EcoRV fragment 8, and a late promoter region within the $5 \mathrm{~kb}$ region downstream of this fragment. 
Early transcripts appeared within the first $10 \mathrm{~min}$ and maximal levels were seen at $10 \mathrm{~min}$. All early transcripts except E7 seem to originate from the intercistronic region between orf4 and orf5. DNA sequencing confirmed that this region contains two divergently orientated consensus promoters, $P_{R}$ and $P_{L}$. Rightwards transcription from $P_{L}$ would result in the observed five transcripts E1, E2, E3, E5 and E8, whilst leftwards transcription from $P_{R}$ would result in transcripts of sizes and positions corresponding to the observed E4 and E6 transcripts.

The $1.5 \mathrm{~kb} \mathrm{E7}$ transcript is located in the same region as the middle transcripts and the $3^{\prime}$ end of the $10 \mathrm{~kb} \mathrm{E1}$ transcript. A possible origin of the E7 transcript could be a site-specific processing of the $10 \mathrm{~kb} \mathrm{E1}$ transcript, resulting in a stable E7 transcript, which is observed during the rest of the infection cycle, and a rapidly and more unspecifically degraded $8.5 \mathrm{~kb} \mathrm{E} 2$ transcript, which has disappeared by $20 \mathrm{~min}$ after the start of the infection cycle. This explanation could furthermore account for the weak and diffuse hybridization signal observed for E2. A similar transcription pattern was observed for the pap gene cluster of Escherichia coli (Båga et al., 1988).

By the end of the early period of infection by a temperate phage a decision towards either the lytic or the lysogenic life cycle is expected to have occurred in every infected cell. In the case of TP901-1, many of the early mRNAs disappear or are significantly reduced between 10 and 20 min. Among the RNAs isolated at later times i.e. at $20 \mathrm{~min}$ or later, we would therefore also expect to find mRNA from the potential lysogens formed in the population. In the case of TP901-1, the frequency of lysogenization is low, about 1-5\% (Koch et al., 1997), and the lysogens thus only constitute a small part of the population. During growth of the lysogenic strains alone, expression of E5 and E6 was found (Fig. 7). From the infection experiment shown in Fig. $6(\mathrm{~b})$ and (d), it can be observed that E6 is initially strongly expressed, then, from 20 min onwards, only very weakly expressed, whilst E5 is present in considerable amounts throughout the infection cycle. With the low frequency of lysogenization observed, the faint expression of E6 at later times might result from the population of lysogens. The strong signal from E5 would thus indicate that this mRNA species is present throughout the infection cycle, either due to continued expression or to unusual stability of the mRNA.

A class of middle transcripts was also detected by use of probe E. These transcripts, M1-M4, could be detected weakly $10 \mathrm{~min}$ after infection, but a dramatic increase in their amounts was observed $30 \mathrm{~min}$ after infection and this level was maintained throughout the rest of the infection cycle. Sequence determinations (L. Brøndsted, unpublished) show that the ORFs in probe $E$ are orientated in the same direction as orf5-orf12. L1-L3 constitute the late class of transcripts, observed $40 \mathrm{~min}$ after infection and onwards. Most likely this transcription occurs in the same direction as the leftward transcription of the early region. This conclusion is based on the orientation of the genes encoding the virion proteins of TP901-1 and the adjacent ORFs (Johnsen et al., 1995, 1996), which are all located on L1-L3. Several attempts to map transcripts to the region located between the end of the L1 transcript and the attachment site of the phage were unsuccessful.

\section{Transcriptional pattern of TP901-1 compared to other lactococcal phages}

The temporal transcription pattern observed for the temperate lactococcal phage TP901-1 thus seems to fit a simple 'cascade model' in which early, middle and late transcribed genes organized in large clusters are sequentially transcribed. The classical example for this type of cascade model of transcription is the coliphage $\lambda$ (for a review see Herskowitz \& Hagen, 1980). Transcriptional analyses have so far only been performed on lytic lactococcal phages. The smaller prolate-headed phages c2 and bIL 67 showed only early and late gene clusters, whilst analysis of the small isometric lytic phage sk 1 belonging to the P008 phage species with no DNA homology to TP901-1, showed early, middle and late classes of transcripts. Seven early, nine middle and four late transcripts were observed, and like TP901-1, the temporal transcription pattern of sk 1 fits a cascade model. The positions of the $5^{\prime}$ ends of the early transcripts of sk1 seem, however, to be more scattered than found in TP901-1 (Beresford et al., 1993). In sk1, early and late transcription are divergently orientated. Interestingly, the late transcripts are also preceded by several short $(0 \cdot 2-1 \cdot 3 \mathrm{~kb})$ middle transcripts, as found for TP901-1. It could be that the triggering of late transription in both phages is initiated though a common mechanism involving processing of a primary transcript.

Two tandem middle promoters have been obtained by cloning from the small isometric phage $\phi 31$ from $L$. lactis, so in this case also several different sizes of middle transcripts are expected (O'Sullivan et al., 1996).

\section{Gene organization in the early region of TP901-1 and similarity to other phages}

A 3690 bp part of the early transcribed region of TP9011 was sequenced in the present study and nine ORFs (orf4-orf12) could be deduced from the sequence data. orf 4 is orientated in the same direction as the previously sequenced orf1-orf 3 , whilst the rest of the ORFs are in the opposite orientation. The related small isometric phage $\mathrm{r} 1 \mathrm{t}$ is the only temperate phage from lactic acid bacteria for which the total sequence of $33350 \mathrm{bp}$ has been published (van Sinderen et al., 1996). The sequence analysis showed that all 50 ORFs except orf1-orf 3 were transcribed from the same DNA strand. A similar gene organization is also possible for TP901-1 since the sequenced genes in the middle and the late region are transcribed from the same strand as orf5-orf12 (Johnsen et al., 1996; L. Brøndsted, personal communication).

Between the two divergent gene clusters in $\mathrm{r} 1 \mathrm{t}$, two 
promoters were identified. The small gene cluster encodes functions needed for lysogeny since orf1 encodes the phage integrase and ORF3, named Rro, was shown to repress the transcription from the lytic promoter (Nauta et al., 1996). A similar gene cluster encoding repressor and integrase has been found in the temperate phages Tuc2009 and BK5-T (van de Guchte et al., 1994a; Boyce et al., 1995a, b). The integrase and the repressors are highly homologous in these phages whilst the integrase (ORF1) and the presumed repressor (ORF4) of TP901-1 are completely different except for a local similarity in ORF4 to the Rro repressor family (Fig. 2). However, the organization of the small gene clusters encoding the functions needed for lysogeny is very similar amongst all the phages, with the presumed repressor as the first transcribed gene and the integrase being the last, located just upstream of the phage attachment site. The local similarity between ORF4 and the identified repressor Rro of $\mathrm{r} 1 \mathrm{t}$ is found in a region of 26 aa in the middle of ORF4, which consists of $180 \mathrm{aa}$. A similar region was found not only in Rro from $r 1 t$ but also in two other phage proteins proposed to be repressors for the phages Tuc2009 and BK5-T (Fig. 2; van de Guchte et al., 1994b; Boyce et al., 1995a). The Cterminal $2 / 3$ of the repressors of $r 1 t$, Tuc2009 and BK5$\mathrm{T}$, which are mutually identical, showed however no similarity to ORF4. In the $\mathrm{N}$ termini of these repressors very little sequence similarity was found, though a putative DNA-binding helix-turn-helix motif was found in all three proteins. This motif was not found in ORF4 (Fig. 2). Also, the putative RecA cleavage site suggested for the other repressors was not found in ORF4. Some limited similarity between ORF4 and the suggested repressor from BK5-T was however discovered in the N-terminal end of the two proteins. That orf 4 encodes the repressor of TP901-1 has now been proven by the finding that a plasmid containing orf 4 confers immunity to infection by TP901-1 when present in the indicator strain 3107 (P. L. Madsen, unpublished results). The fact that all the above-mentioned temperate lactococcal phages, including TP901-1, are induced by mitomycin $\mathrm{C}$ might indicate that RecA is involved in inactivation of the repressor in all cases. The conserved region among the proposed repressors could thus be involved in protein-protein contacts with RecA.

From lysogens of TP901-1, mRNAs corresponding to E5 and $\mathrm{E} 6$ were discovered. These transcripts encode the phage proteins from ORF2 to ORF9, including as expected the repressor (ORF4), but also ORF5 and ORF9, suggested to have Cro-like functions in TP901-1 and BK5-T. Since the RNA was prepared from a mixture of cells, not all cells may contain both transcripts. We would expect E6 mRNA to be present in all lysogens, whilst the presence of E5 mRNA may indicate that partial derepression occurs occasionally in some cells, and because this mRNA species is unusually stable it is detected.

With the exception of the local similarity in ORF4, only ORF12 in TP901-1 showed considerable similarity to a phage protein of known function, namely GP36, which has been shown to be involved in initiation of replication of phage SPP1 from B. subtilis (Pedré et al., 1994). The localization is again equivalent to that found in $\mathrm{r} 1 \mathrm{t}$, where ORF11 and ORF12 are believed to be responsible for phage replication based on protein similarity, but as found for the integrase (ORF1) and the major part of the repressor (ORF4), the TP901-1 proteins were completely different. The finding of DNA replication proteins in the early transcribed region of TP901-1 is in accordance with the observation that initiation of DNA replication is an early event for most phages, though DNA replication continues thoughout the infection cycle (Powell et al., 1992).

The different size transcripts in the early region suggest the presence of either transcriptional terminators or processing sites at several positions in the early region. Studies investigating these possibilities, as well as clarifying the regulation of the $\mathrm{P}_{\mathrm{L}}$ and $\mathrm{P}_{\mathrm{R}}$ promoters, are in progress in our laboratory.

\section{ACKNOWLEDGEMENTS}

This work was supported by grants from the Danish Government Program for Food Science and Technology (FØTEK) through the Center for Lactic Acid Bacteria and the Center for Advanced Food Studies. The support to Karin Hammer from the Foundation of Director Ib Henriksen is also gratefully acknowledged.

\section{REFERENCES}

Arendt, E. K., Daly, C., Fitzgerald, G. F. \& van de Guchte, M. (1994). Molecular characterization of lactococcal bacteriophage Tuc2009 and identification and analysis of genes encoding lysin, a putative holin, and two structural proteins. Appl Environ Microbiol 60, 1875-1883.

Båga, M., Gorransson, M., Normark, S. \& Uhlin, B. E. (1988). Processed mRNA with differential stability in the regulation of E. coli pilin gene expression. Cell 52, 197-206.

Beresford, T. P. J., Ward, L. J. H. \& Jarvis, A. W. (1993). Temporally regulated transcriptional expression of the genomes of lactococcal bacteriophages $\mathrm{c} 2$ and sk1. Appl Environ Microbiol 59, 3708-3712.

Birkeland, N. K. (1994). Cloning, molecular characterization, and expression of the genes encoding the lytic functions of lactococcal bacteriophage $\phi$ LC3 : a dual lysis system of modular design. Can J Microbiol 40, 658-665.

Borodovsky, M. \& Mclninch, J. (1993). Genmark: parallel gene recognition for both DNA strands. Comput Chem 17, 123-133.

Boyce, J. D., Davidson, B. E. \& Hillier, A. J. (1995a). Identification of prophage genes expressed in lysogens of the Lactococcus lactis bacteriophage BK5-T. Appl Environ Microbiol 61, 4099-4104.

Boyce, J. D., Davidson, B. E. \& Hillier, A. J. (1995b). Spontaneous deletion mutants of the Lactococcus lactis temperate bacteriophage BK5-T and localization of the BK5-T attP site. Appl Environ Microbiol 61, 4105-4109.

Braun, V., Jr, Hertwig, S., Neve, H., Geis, A. \& Teuber, M. (1989). Taxonomic differentiation of bacteriophages of Lactococcus lactis by electron microscopy, DNA-DNA hybridization, and protein profiles. J Gen Microbiol 135, 2551-2560.

Bruttin, A., Desiere, F., Lucchini, S., Foley, S. \& Brussow, H. (1997). 
Characterization of the lysogeny DNA module from the temperate Streptococcus thermophilus bacteriophage phi Sfi21. Virology 233, 136-148.

Chandry, P. S., Moore, S. C., Boyce, J. D., Davidson, B. E. \& Hillier, A. J. (1997). Analysis of the DNA sequence, gene expression, origin of replication and modular structure of the Lactococcus lactis lytic bacteriophage sk1. Mol Microbiol 26, 49-64.

Christiansen, B., Johnsen, M. G., Stenby, E., Vogensen, F. K. \& Hammer, K. (1994). Characterization of the lactococcal temperate phage TP901-1 and its site-specific integration. J Bacteriol 176, 1069-1076.

Christiansen, B., Brøndsted, L., Vogensen, F. K. \& Hammer, K. (1996). A resolvase-like protein is required for the site-specific integration of the temperate lactococcal bacteriophage TP901-1. $J$ Bacteriol 178, 5164-5173.

Daly, C., Fitzgerald, G. F. \& Davis, R. (1996). Biotechnology of lactic acid bacteria with special reference to bacteriophage resistance. Antonie Leeuwenhoek 70, 99-110.

Devereux, J., Haeberli, P. \& Smithies, O. (1984). A comprehensive set of sequence analysis programs for the VAX. Nucleic Acids Res 12, 387-395.

Fraser, C. M., Gocayne, J. D., White, O. \& 26 other authors (1995). The minimal gene complement of Mycoplasma genitalium. Science 270, 397-403.

van de Guchte, M., Daly, C., Fitzgerald, G. F. \& Arendt, E. K. (1994a). Identification of int and attP on the genome of lactococcal bacteriophage Tuc2009 and their use for site-specific plasmid integration in the chromosome of Tuc2009-resistant Lactococcus lactis MG1363. Appl Environ Microbiol 60, 2324-2329.

van de Guchte, M., Daly, C., Fitzgerald, G. F. \& Arendt, E. K. (1994b). Identification of the putative repressor-encoding gene cI of the temperate lactococcal bacteriophage Tuc2009. Gene 144, 93-95.

Herskowitz, I. \& Hagen, D. (1980). The lysis-lysogeny decision of phage lambda: explicit programming and responsiveness. Annu Rev Genet 14, 399-445.

Hill, C., Miller, L. A. \& Klaenhammer, T. R. (1990). Cloning, expression, and sequence determination of a bacteriophage fragment encoding bacteriophage resistance in Lactococcus lactis. $J$ Bacteriol 172, 6419-6426.

Himmelreich, R., Hilbert, H., Plagens, H., Pirkl, E., Li, B. C. \& Herrmann, R. (1996). Complete sequence analysis of the genome of the bacterium Mycoplasma pneumoniae. Nucleic Acids Res 24, $4420-4449$.

Jarvis, A. W., Fitzgerald, G. F., Mata, M., Mercenier, A., Neve, H., Powel, I. B., Ronda, C., Saxelin, M. \& Teuber, M. (1991). Species and type phages of lactococcal bacteriophages. Intervirology 32, 2-9.

Jensen, P. R. \& Hammer, K. (1993). Minimal requirements for exponential growth of Lactococcus lactis. Appl Environ Microbiol 59, 4363-4366.

Johnsen, M. G., Neve, H., Vogensen, F. K. \& Hammer, K. (1995). Virion positions and relationships of lactococcal temperate bacteriophage TP901-1 proteins. Virology 212, 595-606.

Johnsen, M. G., Appel, K. F., Madsen, P. L., Vogensen, F. K., Hammer, K. \& Arnau, J. (1996). A genomic region of lactococcal temperate phage TP901-1 encoding major virion proteins. Virology 218, 306-315.

Keogh, B. P. (1973). Adsorption, latent period and burst size of phages of some strains of lactic streptococci. J Dairy Res $\mathbf{4 0}$, 303-309.
Klaenhammer, T. R. (1984). Interactions of bacteriophages with lactic streptococci. Adv Appl Microbiol 30, 1-29.

Koch, B., Christiansen, B., Evison, T., Vogensen, F. K. \& Hammer, K. (1997). Construction of specific erythromycin resistance mutations in the temperate lactococcal bacteriophage TP901-1 and their use in studies of phage biology. Appl Environ Microbiol 63, 2439-2441.

Lillehaug, D. \& Birkeland, N. K. (1993). Characterization of genetic elements required for site-specific integration of the temperate lactococcal bacteriophage $\phi \mathrm{LC} 3$ and construction of integrationnegative $\phi \mathrm{LC} 3$ mutants. J Bacteriol 175, 1745-1755.

Lillehaug, D., Lindqvist, B. H. \& Birkeland, N. K. (1991). Characterization of $\phi \mathrm{LC} 3$, a Lactococcus lactis subsp. cremoris temperate bacteriophage with cohesive single-stranded DNA ends. Appl Environ Microbiol 57, 3206-3211.

Lubbers, M. W., Waterfield, N. R., Beresford, T. P., Le Page, R. W. \& Jarvis, A. W. (1995). Sequencing and analysis of the prolateheaded lactococcal bacteriophage 22 genome and identification of the structural genes. Appl Environ Microbiol 61, 4348-4356.

Ludwig, W., Seewaldt, E., Kilpper-Bälz, R., Schleifer, K. H., Magrum, L., Woese, C. R., Fox, G. E. \& Stackebrandt, E. (1985). The phylogenetic position of Streptococcus and Enterococcus. J Gen Microbiol 131, 543-551.

Madsen, P. L. (1996). Transcription of the lactococcal temperate phage TP901-1. PhD thesis, University of Copenhagen.

Moineau, S., Fortier, J., Ackermann, H. W. \& Pandian, S. (1992). Characterization of lactococcal bacteriophages from Quebec cheese plants. Can J Microbiol 38, 875-882.

Nauta, A., van Sinderen. D., Karsens. H., Smit, E., Venema, G. \& Kok, J. (1996). Inducible gene expression mediated by a repressoroperator system isolated from Lactococcus lactis bacteriophage r1t. Mol Microbiol 19, 1331-1341.

O'Sullivan, D. J., Hill, C. \& Klaenhammer, T. R. (1993). Effect of increasing the copy number of bacteriophage origins of replication, in trans, on incoming-phage proliferation. Appl Environ Microbiol 59, 2449-2456.

O'Sullivan, D. J., Walker, S. A., West, S. G. \& Klaenhammer, T. R. (1996). Development of an expression strategy using a lytic phage to trigger explosive plasmid amplification and gene expression. Bio/Technology 14, 82-87.

Pedré, X., Weise, F., Chai, S., Luder, G. \& Alonso, J. C. (1994). Analysis of $c$ is and trans acting elements required for the initiation of DNA replication in the Bacillus subtilis bacteriophage SPP1. $J$ Mol Biol 236, 1324-1340.

Powell, I. B., Tulloch, D. L., Hillier, A. J. \& Davidson, B. E. (1992). Phage DNA synthesis and host DNA degradation in the life cycle of Lactococcus lactis bacteriophage c6A. J Gen Microbiol 138, 945-950.

Sambrook, J., Fritsch, E. F. \& Maniatis, T. (1989). Molecular Cloning: a Laboratory Manual, 2nd edn. Cold Spring Harbor, NY : Cold Spring Harbor Laboratory.

Sanders, M. E. (1987). Bacteriophages of industrial importance. In Phage Ecology, pp. 211-244. Edited by S. M. Goyal, C. P. Gerba $\&$ G. Bitton. New York: Wiley Interscience.

Sanger, F., Nicklen, S. \& Coulson, A. R. (1977). DNA sequencing with chain-terminating inhibitors. Proc Natl Acad Sci 74, 5463-5467.

Schouler, C., Ehrlich, S. D. \& Chopin, M.-C. (1994). Sequence and organization of the lactococcal prolate-headed bIL67 phage genome. Microbiology 140, 3061-3069. 
Shearman, C., Underwood, H., Jury, K. \& Gasson, M. (1989). Cloning and DNA sequence analysis of a Lactococcus bacteriophage lysin gene. Mol Gen Genet 218, 214-221.

van Sinderen, D., Karsens, H., Kok, J., Terpstra, P., Ruiters, M. H., Venema, G. \& Nauta, A. (1996). Sequence analysis and molecular characterization of the temperate lactococcal bacteriophage $\mathrm{r} 1 \mathrm{t}$. Mol Microbiol 19, 1343-1355.
Terzaghi, B. E. \& Sandine, W. E. (1975). Improved medium for lactic streptococci and their bacteriophages. Appl Microbiol 29, 807-813.

Received 22 December 1997; revised 16 April 1998; accepted 27 April 1998. 